\title{
A User Survey on the Interface Causing Discomfort for Warning
}

\author{
Yasuhiro Fujihara and Yuko Murayama \\ Iwate Prefectural University \\ Japan
}

\section{Introduction}

Security technology has been evaluated in terms of theoretical and engineering feasibility and mostly from the viewpoint of service providers. However, there has been no evaluation from the viewpoint of users. The term "security" includes objective viewpoints of security engineering and subjective factors such as sense of security. We have introduced the concept of "Anshin" (Hikage et al., 2007; Murayama et al., 2007). Anshin is a Japanese noun that literally means "to ease one's mind". We have used this term to indicate the sense of security.

Since research on information security has been focused on its cognitive aspect, it is difficult to find specific studies related to the emotional aspect. On the other hand, some researchers have been considering the emotional aspects of trust. According to Xiao \& Benbasat (2004), emotional trust is a feeling, whereas cognitive trust is cognition. Emotional trust is the feeling of interpersonal sensitivity and support (McAllister, 1995), that is, feeling secure about the trustee. More recent studies have accounted for the emotional aspects of trust in their frameworks for trust in electronic environments as well (Chopra \& Wallace, 2003; Kuan \& Bock, 2005). Luhmann (2000) reports on the relation between trust and confidence. Confidence is also an expectation that may lapse into disappointments. The distinction between confidence and trust is whether $\mathrm{s} / \mathrm{he}$ is willing to consider alternatives. If $\mathrm{s} / \mathrm{he}$ does not consider alternatives, they are in a situation of confidence.

We explored an interesting concept in which an interface causing discomfort could let a user achieve Anshin, because the user would be aware of the danger and risks involved (Oikawa, 2008; Fujihara et al., 2008). In this paper, we report on the initial model of the discomfort felt by a user when using a computer. We use services and systems on the Internet under many security threats such as computer viruses and phishing. Quite often, users are unaware of such security threats; therefore, they do not take any countermeasures. We have investigated some factors of feelings of discomfort and constructed a causal structural model of discomfort in order to create an interface that causes discomfort.

\section{Interface causing discomfort}

In this section, we introduce an interface causing discomfort; the interface is described in terms of its constructions and applications.

Source: User Interfaces, Book edited by: Rita Mátrai,

ISBN 978-953-307-084-1, pp. 270, May 2010, INTECH, Croatia, downloaded from SCIYO.COM 


\subsection{Unusability}

Human interfaces have been researched to a great extent in terms of usability (Nielsen, 1993). On the other hand, researches have also been carried out on methods to avoid human errors in safety engineering. Some interfaces are deliberately designed such that it is difficult to operate the systems that employ them. Examples of such systems that are intentionally made difficult to use include

- A system used for blasting dynamite. It is designed in such a way that it is not easy to trigger the blast; that is, one has to press two switches simultaneously to initiate the explosion. Such a design has been recommended in military installations (Norman, 1988).

- The fail-safe design of a microwave oven. According to the International Electrotechnical Commission (1996), a microwave oven should be designed such that is not possible to operate it without shutting the door (IEC 60335-2-25).

Such hard-to-use interfaces have also been used in the electronic space. When a user is going to execute erroneous operations, the system would display a warning message window and ask the user to answer "Yes" or "No" to proceed. However, the problem is that users tend to answer "Yes" in order to proceed, without fully understanding the warning message.

\subsection{Applications of feelings of discomfort}

According to an experimental test by Mackie et al. (1989), when the receiver of a message was comfortable, s/he would form a reply based on the professionalism of the persuader. On the other hand, when the receiver was uncomfortable, s/he would form a reply based on the semantics of the message. This experiment shows that the feeling of discomfort would persuade the user to take a cautious decision.

\subsection{Methods of causing discomfort}

Methods that can cause discomfort to a user might include designing a system that makes it difficult to see or hear through the output device of a computer, makes the user to input and search for information or files, or makes a computer run slowly.

It is also possible to use the sense of touch in order to cause discomfort. Ishii et al. (1997) suggested user interfaces that employ tangible devices. For example, it is possible to manufacture parts of a computer using certain materials and in certain shapes such that these parts would cause a tactile sensation, vibration, or temperature change when touched by the user.

\subsection{Possible applications of interface causing discomfort}

An interface causing discomfort would raise the user's attention when a warning message is displayed on a computer. For example, some users choose "Yes" without reading warning messages about expired server certification. We believe that we can raise the user's attention to the warning message by applying discomfort interface principles to the design of the warning. Sankarapandian et al. (2008) suggested an interface to make the user aware about the vulnerabilities posed by unpatched software. They implemented a desktop with annoying graffiti that showed the number and seriousness of vulnerabilities. Egelman et al. (2008) carried out an experiment on the rate to avoid the damage caused by phishing; the experiment was based on a C-HIP (Communication-Human Information Processing) model 
(Wogalter, 2006) in which the interface warns users about vulnerabilities. They reported that the user responses to a warning differed depending on the type of interface used.

In addition, an application concept exists to avoid accidents caused by the wrong usage of industrial products in the real world. This concept involves the application of a discomfort interface to the warning message label of a product or dangerous parts of the product so that users will not touch those parts.

Design for awareness of danger is highly interdisciplinary. Generally, red denotes a command to "stop" (International Organization for Standardization, 2002). In fact, road traffic signs and crossing bars are mostly red and white. However, the color red cannot be easily recognized by all human beings. We can raise the user's awareness of danger by adding a discomfort interface to warning information.

\section{User survey}

\subsection{Identification of elements causing discomfort}

We have investigated the factors causing feelings of discomfort, first, by finding the elements (hereinafter called the discomfort elements) that cause discomfort to users, and second, by identifying the factors of discomfort with the use of factor analysis. We identified discomfort elements by two methods: a literature survey and a preliminary test.

From the literature survey, we identified several elements that caused discomfort to a user (Ramsay, 1997; Awad \& Fitzgerald 2005; Takahashi et al., 2002). Moreover, Tsuji et al. (2005) and Hagiwara (2006) investigated the degree of discomfort in daily life. In their studies, they used stimulus sentences in order to stimulate subjects. We derived discomfort elements from their stimulus sentences as well. In this manner, we identified the following discomfort elements: a user cannot use a computer well, malfunctions of the system due to spyware, blast of a siren, noise of television, a sudden telephone ring at night, sight of bugs or crawlers, etc.

In our preliminary test, we asked subjects for their opinions about situations and events that cause discomfort. In this manner, we identified the following discomfort elements: waiting for a computer process to finish, popping up of a system message and advertisements, a computer getting stalled/hanged, eyestrain, etc.

For further analysis, we selected discomfort elements from the opinions. The subjects of the preliminary test included twenty two undergraduate students from the faculty of Software and Information Science of our university; sixteen of them were males and six were females. We asked them their opinions and feelings in detail about "dislike," "a bit of a bind," "bothering" and "hurtful" matters when they use a computer and the Internet daily.

\subsection{Review of the questionnaire}

We created eighty six questions for simulating discomfort; the questions were based on the discomfort elements selected from our preliminary survey. We asked subjects to rate each discomfort element. The rates included five ranks: from calm (zero points) to acute discomfort (four points).

We conducted a user survey in order to review the questionnaire. In total, seventy five men and eighty seven women of the first-year students from four different departments participated in the survey. The survey was conducted from May 8, 2007 for one week. On the basis of the survey results, we revised some questions. 


\begin{tabular}{|c|c|c|c|c|c|}
\hline No. & Question & mean & S.D. & skewness & kurtosis \\
\hline 01 & It takes so long to boot up a computer. & 2.86 & 0.94 & -0.49 & -0.37 \\
\hline 02 & It takes so long to shut down a computer. & 1.83 & 1.27 & 0.25 & -0.61 \\
\hline 03 & $\begin{array}{l}\text { A computer works slowly due to a useful } \\
\text { operation such as virus check. }\end{array}$ & 2.30 & 1.16 & 0.00 & -0.69 \\
\hline 04 & $\begin{array}{l}\text { A computer works slowly due to poor } \\
\text { performance of the computer }\end{array}$ & 3.02 & 0.78 & -0.57 & -0.05 \\
\hline 05 & A computer has been freezing. & 3.37 & 0.75 & -1.37 & 1.60 \\
\hline 06 & $\begin{array}{l}\text { You get an error message and can not complete } \\
\text { the operation you need. }\end{array}$ & 2.80 & 0.96 & -0.47 & -0.31 \\
\hline 07 & $\begin{array}{l}\text { You get a system message to ask you to confirm } \\
\text { whenever you try and start a specific operation }\end{array}$ & 2.07 & 1.16 & 0.04 & -0.55 \\
\hline 08 & $\begin{array}{l}\text { A computer restarted unexpectedly while you } \\
\text { were using it. }\end{array}$ & 3.04 & 1.00 & -0.80 & -0.04 \\
\hline 09 & $\begin{array}{l}\text { You get a system message on a display to ask } \\
\text { you whether you would like to update some } \\
\text { software or not. }\end{array}$ & 1.82 & 1.11 & 0.33 & -0.37 \\
\hline 10 & The computer is infected with a computer virus. & 3.64 & 0.55 & -2.21 & 4.54 \\
\hline 11 & The computer display suddenly blacks out. & 3.23 & 0.80 & -0.96 & 0.16 \\
\hline 12 & $\begin{array}{l}\text { New software was installed automatically } \\
\text { without consideration to your wishes. }\end{array}$ & 2.80 & 1.25 & -0.72 & -0.21 \\
\hline 13 & $\begin{array}{l}\text { You try and start a prohibited operation and get } \\
\text { prevented from doing so. (e.g. restricted } \\
\text { operation) }\end{array}$ & 1.86 & 1.36 & 0.27 & -0.73 \\
\hline 14 & $\begin{array}{l}\text { You heard suddenly a loud noise from a pair of } \\
\text { speakers or through a headset. }\end{array}$ & 2.65 & 1.18 & -0.46 & -0.47 \\
\hline 15 & $\begin{array}{l}\text { You heard repeated sounds from computer for } \\
\text { a long time. }\end{array}$ & 2.53 & 1.16 & -0.36 & -0.59 \\
\hline 16 & $\begin{array}{l}\text { It takes so long to get an access to and display a } \\
\text { web site. }\end{array}$ & 2.79 & 0.92 & -0.50 & -0.08 \\
\hline 17 & $\begin{array}{l}\text { You set up a LAN cable correctly but cannot } \\
\text { connect to the internet. }\end{array}$ & 2.85 & 1.00 & -0.73 & 0.17 \\
\hline 18 & $\begin{array}{l}\text { You get connected to the internet from time to } \\
\text { time. }\end{array}$ & 3.05 & 0.78 & -0.78 & 0.39 \\
\hline 19 & $\begin{array}{l}\text { It is hard to grasp what information is available } \\
\text { and where it is. }\end{array}$ & 2.49 & 1.02 & -0.25 & -0.49 \\
\hline 20 & $\begin{array}{l}\text { You see advertisements displayed on the } \\
\text { website. }\end{array}$ & 1.66 & 1.44 & 0.48 & -0.68 \\
\hline 21 & $\begin{array}{l}\text { You are not sure whether the information on a } \\
\text { website is accurate or not. }\end{array}$ & 1.88 & 1.21 & 0.22 & -0.60 \\
\hline 22 & $\begin{array}{l}\text { It is hard for you to see information on the } \\
\text { website due to its background color. }\end{array}$ & 2.26 & 1.03 & -0.03 & -0.35 \\
\hline 23 & $\begin{array}{l}\text { It is hard for you to find information which you } \\
\text { are looking for on the web site. }\end{array}$ & 2.36 & 0.97 & -0.25 & -0.13 \\
\hline
\end{tabular}




\begin{tabular}{|c|c|c|c|c|c|}
\hline 24 & $\begin{array}{l}\text { You cannot see a web site due to unsupported } \\
\text { functions with your web browser }\end{array}$ & 2.51 & 1.04 & -0.41 & -0.07 \\
\hline 25 & When you saw unpleasant graphics or texts. & 2.69 & 1.34 & -0.61 & -0.44 \\
\hline 26 & $\begin{array}{l}\text { You come across a website which makes too } \\
\text { much usage of Flash. }\end{array}$ & 1.88 & 1.48 & 0.09 & -0.98 \\
\hline 27 & $\begin{array}{l}\text { When you heard sounds or music } \\
\text { unexpectedly. }\end{array}$ & 2.33 & 1.21 & -0.05 & -0.79 \\
\hline 28 & $\begin{array}{l}\text { You get a system message suddenly to ask you } \\
\text { whether you would like to update some } \\
\text { software or not. }\end{array}$ & 1.71 & 1.10 & 0.39 & -0.34 \\
\hline 29 & $\begin{array}{l}\text { You get too many pop-up advertisements on a } \\
\text { display. }\end{array}$ & 2.77 & 1.09 & -0.50 & -0.37 \\
\hline 30 & $\begin{array}{l}\text { When you saw a web site with too many banner } \\
\text { advertisements. }\end{array}$ & 2.11 & 1.33 & -0.04 & -0.78 \\
\hline 31 & You read texts in too small font size. & 1.75 & 0.97 & 0.30 & -0.29 \\
\hline 32 & $\begin{array}{l}\text { You need to read too long messages on a web } \\
\text { page. }\end{array}$ & 1.77 & 1.06 & 0.11 & -0.45 \\
\hline 33 & You need to keep scrolling to read a document. & 1.46 & 1.01 & 0.56 & 0.02 \\
\hline 34 & You forgot a password. & 2.20 & 1.04 & 0.02 & -0.53 \\
\hline 35 & $\begin{array}{l}\text { You need to input too long URL (website } \\
\text { address). }\end{array}$ & 2.45 & 1.45 & -0.39 & -0.74 \\
\hline 36 & You are asked to input your ID and password. & 1.59 & 1.32 & 0.45 & -0.47 \\
\hline 37 & $\begin{array}{l}\text { You need to input too many personal } \\
\text { information items }\end{array}$ & 2.22 & 1.24 & -0.13 & -0.62 \\
\hline 38 & $\begin{array}{l}\text { You need to input some personal information } \\
\text { which you do not like to do so. }\end{array}$ & 2.66 & 1.06 & -0.41 & -0.33 \\
\hline 39 & $\begin{array}{l}\text { When you press a key where it is difficult for } \\
\text { your fingers to reach on your keyboard. }\end{array}$ & 1.37 & 1.37 & 0.61 & -0.42 \\
\hline 40 & It is hard to control a mouse pointer. & 2.52 & 0.95 & -0.06 & -0.45 \\
\hline 41 & $\begin{array}{l}\text { You need to install more extra software in order } \\
\text { to install one software. }\end{array}$ & 2.25 & 1.13 & -0.17 & -0.47 \\
\hline 42 & $\begin{array}{l}\text { When you input Kanji characters, you cannot } \\
\text { get the result of the Kanji conversion as you } \\
\text { wish. }\end{array}$ & 2.16 & 1.18 & 0.07 & -0.62 \\
\hline 43 & $\begin{array}{l}\text { Your texts are transformed with the auto-correct } \\
\text { function. }\end{array}$ & 2.05 & 1.20 & 0.12 & -0.62 \\
\hline 44 & It is hard to understand how to use software. & 2.45 & 1.04 & -0.24 & -0.28 \\
\hline 45 & $\begin{array}{l}\text { You look for a particular window out of too } \\
\text { many windows. }\end{array}$ & 1.84 & 1.31 & 0.08 & -0.77 \\
\hline 46 & $\begin{array}{l}\text { It is hard to find software or files you are } \\
\text { looking for. }\end{array}$ & 2.24 & 0.98 & -0.11 & -0.25 \\
\hline
\end{tabular}

Note: The rates included five ranks: from calm (zero points) to acute discomfort (four points).

Table 1. Details of the questions 


\subsection{Survey design}

We have conducted an extensive user survey in order to measure the degree of discomfort caused by the individual discomfort elements. We prepared forty six questions for simulating discomfort on the basis of the results of our preliminary test. Some of the questions are listed in Table 1.

In total, one hundred forty six men and one hundred sixty four women of the second-, third, and fourth-year students from four different departments participated the survey. The survey was conducted from November 14, 2007 for one week.

From the three hundred thirteen data records collected, we discarded three data records as invalid, including those involving multiple answers, thereby leaving three hundred ten data records to be used for analysis. Breakdown of the three hundred ten data records: forty nine correspond to the faculty of Nursing; fifty two, to the faculty of Social Welfare; one hundred thirty four, to the faculty of Software and Information Science; and seventy five, to the faculty of Policy Studies. The average age of the subjects was approximately 20.38 years. Most subjects had completed the course on liberal arts of computer use and used a computer daily.

\section{Factors of discomfort}

\subsection{Exploratory factor analysis}

We analyzed the three hundred ten data records by carrying out exploratory factor analysis using the maximum likelihood method. Harman (1976) introduced details about factor analysis. For the analysis, we used SPSS $14.0 \mathrm{~J}^{\mathrm{TM}}$ for Windows. Here, we explain the procedure of factor analysis. First, the analyst selects questions for analysis, carries out an initial analysis, and calculates the initial solution. Second, the analyst decides the number of factors by various standards based on the initial solution and performs the second analysis with a fixed number of factors. When several numbers of factors are possible, the analyst adopts the number of factors is determined according to how possibly interpretable the chosen factors would be. Depending on the results of this analysis, the analyst makes some changes, such as selecting questions again or changing the number of factors, and repeats analyses.

We carried out the initial analysis with the maximum likelihood method and a promax rotation. Figure 1 is a graph called scree plot for determining the number of factors from the eigenvalues. From the attenuation of eigenvalues from the initial analysis and the ease of factor interpretation, we adopt the seven-factor solution.

There were five questions $(05,10,12,25,39)$ that exerted a ceiling effect, two questions (04, 15) that exhibited high factor loading on two factors, and one question (36) that did not exhibit high factor loading for any of the factors. We excluded these questions and carried out the factor analysis once more for the remaining thirty eight questions.

Table 2 lists the values of the factor pattern matrix of three questions that exhibited high loading on their respective factors. Table 3 lists the values of the factor correlation matrix obtained by carrying out exploratory factor analysis using the maximum likelihood method and the promax rotation.

Factor 1: "Hassle" consists of eleven high factor loading items related to looking for things that are difficult to find or to input information using a keyboard or a mouse. 


\begin{tabular}{|c|c|c|c|c|c|c|c|c|}
\hline & F1 & $\mathrm{F} 2$ & F3 & F4 & F5 & F6 & F7 & $\begin{array}{c}\text { Commo- } \\
\text { nality }\end{array}$ \\
\hline Q45 You look for a particular window out of too many windows. & .745 & .055 & .098 & -.137 & -.027 & -.003 & -.009 & .529 \\
\hline Q46 It is hard to find software or files you are looking for. & .655 & -.023 & -.033 & .141 & .141 & -.020 & -.054 & .640 \\
\hline Q43 Your texts are transformed with the auto-correct function. & .644 & .052 & .098 & -.165 & -169 & .016 & .040 & .319 \\
\hline $\begin{array}{l}\text { Q42 When you input Kanji characters, you cannot get the result of the } \\
\text { Kanji conversion as you wish. }\end{array}$ & .593 & .004 & .051 & -.148 & -.003 & .222 & $\begin{array}{l}2.043 \\
\end{array}$ & .450 \\
\hline $\begin{array}{l}\text { Q41 You need to install more extra software in order to install one } \\
\text { software. }\end{array}$ & .582 & .036 & .183 & .122 & -.029 & -.126 & -.079 & .319 \\
\hline $\begin{array}{l}\text { Q38 You need to input some personal information which you do not } \\
\text { like to do so. }\end{array}$ & .552 & -.016 & -.245 & 076 & -.032 & .057 & 7.092 & .311 \\
\hline Q37 You need to input too many personal information items. & .549 & -.025 & .006 & -.021 & -.054 & .097 & 7.097 & .335 \\
\hline Q40 It is & .534 & .150 & -.188 & .106 & -.120 & .095 & 5.058 & .397 \\
\hline Q44 It is & .509 & .118 & -.085 & .142 & .186 & -.063 & -.043 & .542 \\
\hline Q36 You & .482 & -.148 & .171 & .036 & .211 & -.136 & -.006 & .413 \\
\hline Q34 You forgot a password. & .418 & .085 & -.020 & .038 & .071 & -.144 & .110 & .278 \\
\hline $\begin{array}{l}\text { Q21 You are not sure whether the information on a website is accurate } \\
\text { or not. }\end{array}$ & .126 & .803 & -.002 & -107 & .080 & -.016 & $\begin{array}{r}-.230 \\
\end{array}$ & .604 \\
\hline $\begin{array}{l}\text { Q22 It is hard for you to see information on the website due to its } \\
\text { background color. }\end{array}$ & .038 & .707 & -.159 & -.145 & .097 & .086 & .084 & .534 \\
\hline tisements displayed on the website. & -.045 & .663 & .249 & -.030 & -.163 & -.021 & -.040 & .459 \\
\hline Q29 & -.138 & .553 & .009 & .170 & -.206 & -.028 & 342 & .565 \\
\hline vertisements. & .004 & .497 & .081 & -.002 & -.033 & -145 & 340 & .489 \\
\hline $\begin{array}{l}\text { Q24 You cannot see a website due to unsupported functions with } \\
\text { your web browser. }\end{array}$ & .179 & .430 & -.034 & .176 & .066 & .000 & -100 & .423 \\
\hline or you to find information which you are looking for & .063 & .414 & .037 & .096 & .182 & .131 & -.058 & .469 \\
\hline $\mathrm{d}$ to grasp what information is available and where it is. & .097 & .392 & -.058 & .245 & .068 & .027 & 7.013 & .429 \\
\hline $\begin{array}{l}\text { a display to ask you whether you } \\
\text { re or not. }\end{array}$ & - & -.008 & .699 & 107 & .024 & .141 & $1-060$ & .526 \\
\hline $\begin{array}{l}\text { Q13 You try and start a prohibited operation and get prevented from } \\
\text { doing so. (e.g. restricted operation) }\end{array}$ & .155 & -.041 & .602 & .089 & -.091 & -.088 & 3.082 & .454 \\
\hline $\begin{array}{l}\text { addenly to ask you whether you } \\
\text { are or not. }\end{array}$ & -.122 & .171 & .589 & -.019 & .215 & -.023 & .152 & .581 \\
\hline $\begin{array}{l}\text { Q03 A computer works slowly due to a useful operation such as virus } \\
\text { check. }\end{array}$ & .160 & -.112 & .435 & .015 & -.159 & .358 & .031 & .436 \\
\hline $\begin{array}{l}\text { Q07 You get a system message to ask you to confirm whenever you } \\
\text { try and start a specific operation. }\end{array}$ & .098 & .051 & .406 & .111 & -.106 & .092 & .014 & .307 \\
\hline$\overline{\text { Q17 You set up a LAN cable correctly }}$ & -.072 & .066 & .119 & .681 & .124 & -.062 & $2-.087$ & .541 \\
\hline re using it. & -.051 & -.002 & .046 & .591 & -.235 & .008 & .113 & .318 \\
\hline m time to time. & -.027 & -.011 & -.013 & .562 & .036 & .293 & .066 & .583 \\
\hline Q11 The computer display & .240 & -.238 & .026 & .482 & .038 & -.137 & $7-.001$ & .293 \\
\hline $\begin{array}{l}\text { Q06 You get an error message and cannot complete the operation you } \\
\text { need. }\end{array}$ & .084 & .072 & .239 & .410 & -.064 & .069 & -099 & .382 \\
\hline 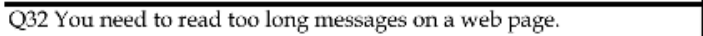 & -.030 & -.071 & -.025 & -.038 & .830 & .109 & .094 & .649 \\
\hline Q31 W & .034 & .104 & -.090 & -.072 & .675 & .004 & .068 & .485 \\
\hline Q33 You & .273 & -.071 & .168 & .044 & .450 & .028 & 3.040 & .507 \\
\hline Q01 It takes so long to boot up a computer. & -.053 & -.011 & .054 & .059 & .074 & .801 & -.030 & .702 \\
\hline Q16 It takes so long to get an access to and displa & .038 & -.044 & -.023 & .303 & .071 & .536 & .062 & .702 \\
\hline Q02 It takes so long to shut down a computer. & -.014 & .109 & .295 & -.246 & .048 & .481 & -.057 & .343 \\
\hline Q27 When you $\mathrm{h}$ & .106 & .017 & -.020 & -.068 & .111 & -.002 & .702 & .558 \\
\hline $\begin{array}{l}\text { Q14 You heard suddenly a loud noise from a pair of speakers or } \\
\text { through a headset. }\end{array}$ & .063 & -.1 & .058 & .133 & .049 & .023 & .534 & .345 \\
\hline \multirow[t]{4}{*}{ Q26 You come across a website which makes too much usage of Flash. } & .039 & .069 & .138 & -.048 & .214 & -.026 & .425 & .360 \\
\hline & 11.22 & 2.40 & 2.03 & 1.70 & 1.41 & 1.34 & 1.22 & \\
\hline & 29.52 & 6.32 & 5.35 & 4.48 & 3.72 & 3.54 & 3.20 & \\
\hline & 29.52 & 35.84 & 41.19 & 45.68 & 49.40 & 52.94 & 56.13 & \\
\hline
\end{tabular}

Table 2. Factor pattern matrix 


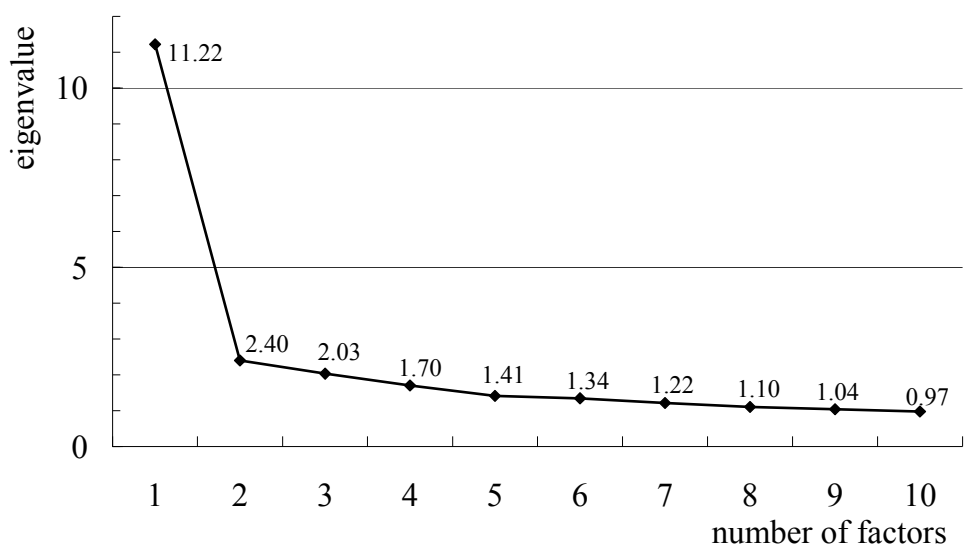

Fig. 1. The scree plot for determining the number of factors from the eigenvalues

\begin{tabular}{|c|c|c|c|c|c|c|c|}
\hline & I & II & III & IV & $\mathrm{V}$ & VI & VII \\
\hline I & - & .527 & .462 & .599 & 651 & .423 & .309 \\
\hline II & & - & .398 & .482 & .403 & .384 & .460 \\
\hline III & & & - & .364 & .344 & .346 & .309 \\
\hline IV & & & & - & .444 & .499 & .276 \\
\hline V & & & & & - & .289 & .128 \\
\hline VI & & & & & & - & .313 \\
\hline VII & & & & & & & - \\
\hline
\end{tabular}

Table 3. Factor pattern matrix

Factor 2: "Search Information" consists of eight high factor loading items related to a situation in which a user is attempting to find information that is difficult to locate.

Factor 3: "Message" consists of seven high factor loading items related with messages that interrupt a user's activity.

Factor 4: "Unexpected Operation" consists of five high factor loading items related with a system malfunction that is unexpected or unintended by a user.

Factor 5: "Hard to See" consists of three high factor loading items related with the sense of sight given by a physical aspect.

Factor 6: "Waiting Time" consists of three high factor loading items related with waiting time and system delay.

Factor 7: "Sound" consists of three high factor loading items related with the sense of hearing given by a particular sound.

The seven factors include thirty eight items in total and explained $56.1 \%$ of the total variance. Further, the internal consistency of each factor was as follows: (Cronbach's coefficient alpha $=0.867$ for Factor 1, 0.842 for Factor 2, 0.771 for Factor 3, 0.731 for Factor 4, 0.757 for Factor 5, 0.699 for Factor 6, and 0.649 for Factor 7). Table 3 presents the list of the item numbers in a descending order according to factor loading. 


\subsection{Construction of a causal structural model of discomfort}

Yamazaki \& Kikkawa (2006) suggested that there is a structure in Anshin, through their study on Anshin in an epidemic disease. They inspected the validity of our model by using structural equation modeling (SEM). We also constructed a causal structural model of discomfort based on the seven factors of discomfort identified in the previous section.

Structural equation modeling (SEM) is a statistical approach that is used to verify the validity of a hypothesis as a causal model. Kline (2005) introduced details about SEM. We used SEM to examine what types of causal relationships would be possible between the factors of discomfort. For quantifying the degree of validity of a model, we adopted three fit indexes, viz., GFI, CFI, and RMSEA ${ }^{1}$ Please refer (Bollen \& Long, 1993) for more detailed introduction to fit indexes used in SEM.

In the model representation of SEM a construct that is measured directly is called an "observed variable" and shown as a square. On the other hand, a construct that is not measured directly is called a "latent variable" and shown as an oval. Further, in the model representation of SEM, a result is decided by a cause. However, some parts of the result are not explained by the cause. These parts are called "error terms" in the case of observed variables and "nuisance" in the case of latent variables.

A causal relationship between variables is shown as a straight allow and called a "path." The numbers shown adjoining such arrow or paths are the path coefficients, which signify the strength of the causal relationships.

With the seven factors of discomfort, we prepared the variance-covariance matrix of the factor score, connected the high-score pairs of factors, and created a path diagram. We selected three to five items of each factor as observed variables for SEM. For the analysis, we used AMOS 6.0 ${ }^{\mathrm{TM}}$ for Windows.

Figure 2 shows our structural causal model of discomfort. We found that the model is generally appropriate (fit indexes: GFI (0.867), CFI (0.867), and RMSEA (0.067)). The names of observed variables in Figure 2 correspond to the ones listed in Table 1 . The variables e1 to e24 are error terms, and $\mathrm{d} 1$ to $\mathrm{d} 7$ are nuisance variables. Further, the path coefficients are computed as standardized estimates with the standardized variance of the observed variables set to 1 . There are some paths that have no computed significance probability because the fixed path coefficients of the observed variables are located on the top of the observed variables to 1 in each factor to save the discrimination of the model.

1 GFI is the goodness-of-fit index. GFI varies from 0 to 1 , but theoretically can yield meaningless negative values. By convention, a GFI should be equal to or greater than 0.90 to accept the model. By this criterion, the present model is accepted.

CFI is the comparative fit index, which varies from 0 to 1 . A CFI close to 1 indicates a very good fit, and values above 0.90 indicate an acceptable fit.

RMSEA is root mean square error of approximation. RMSEA is selected as the suitable model. By convention, there is good model fit if the RMSEA is less than 0.05; adequate fit, if the RMSEA is less than 0.08 . 


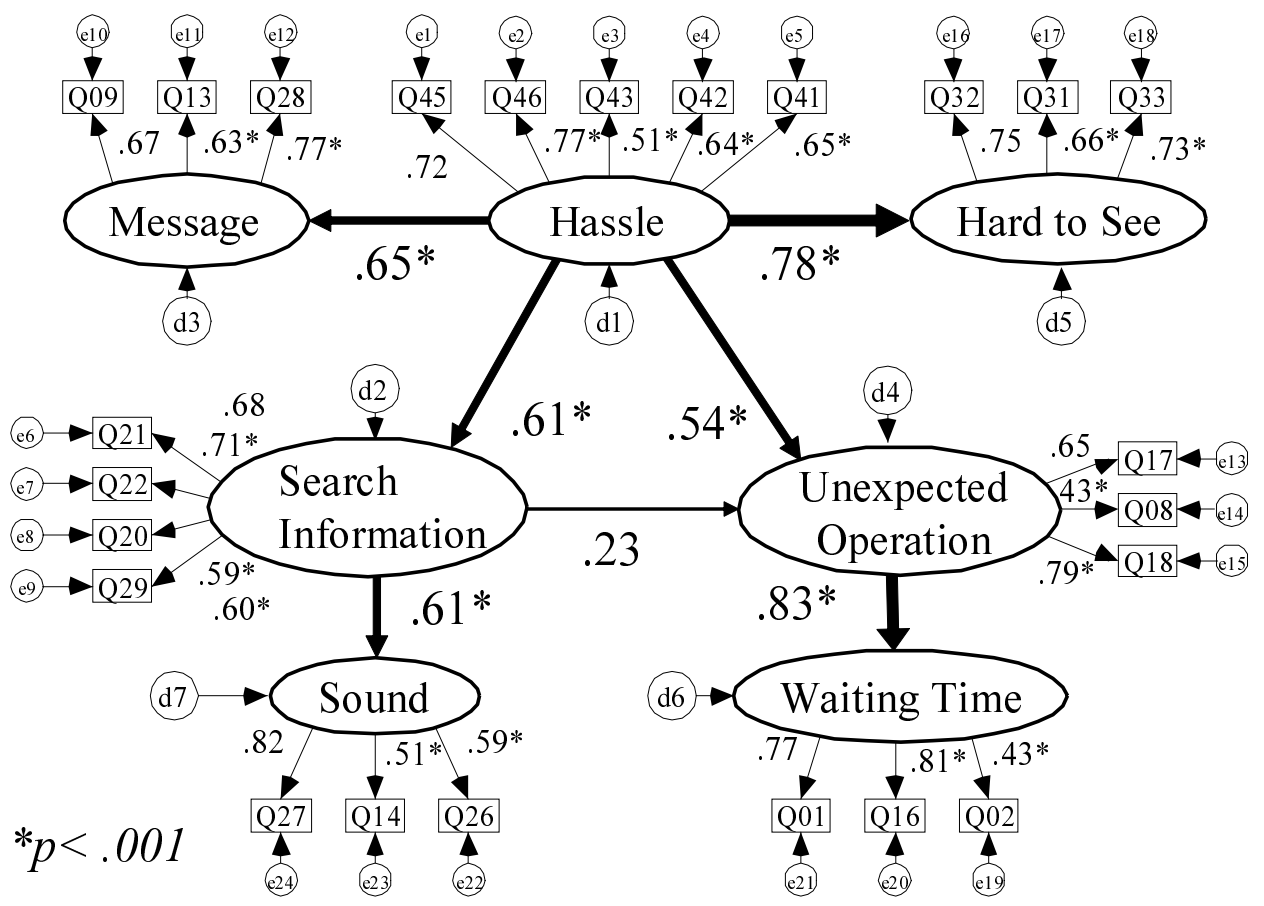

Fig. 2. Structural causal model of discomfort

\section{Discussion}

We conducted a survey in which we questioned the subjects about the time they spend on a PC. Among the subjects, one hundred eighty nine persons responded that they spent more than ten hours a week on a PC. We examined how the experience of using a PC caused the users to feel discomfort. By dividing the subjects into a group that used a PC for more than ten hours a week (frequent-user group) and another group that used a PC for less than ten hours a week (less-frequent-user group), the difference between the average scores of the seven factors was reviewed by a t-test.

As for the Hard to See factor, the less-frequent-user group exhibited significantly higher scores than those exhibited by the frequent-user group. This result indicated that the users who spent less time on a PC tended to feel severe discomfort about poor viewability, as compared to those who spent more time on a PC. With regard to the factors Search information and Sound, the frequent-user group exhibited significantly higher scores than those exhibited by the less-frequent-user group. This result also indicated that the users who spent more time on a PC tended to strongly feel discomfort about retrieval of information or noise, as compared to those who spent less time on a PC. Since significant differences were not found in the other factors, the discomfort about the factors Hassle, Message, Unexpected Operation, and Waiting Time seem less likely to be affected by the amount of time spent on a PC.

As shown in Figure 2, the Hassle factor is at the core of the seven factors. The Search Information factor and the Unexpected Operation factor have a number of paths to the other 
factors; the coefficients for those paths have high values, which indicate that these two factors have a strong affect on the other factors.

The Hassle factor has a significant effect on the factors Hard to See, Message, Search Information, and Unexpected Operation. Further, the factor Search Information has significant effects on the factors Sound and Unexpected Operation. The factor Unexpected Operation has a significant effect on the factor Waiting Time. Moreover, the path coefficient between these two factors is highest; therefore, we considered that the two factors have a strong causal relationship.

Although the factors Message, Hard to See, Waiting Time, and Sound have a strong effect on the questionnaire items, which appear as dependent variables, they have a little effect on the other factors. Therefore, these factors are considered as somewhat independent.

The structural model, even in its current preliminary form, suggests that user interfaces that cause discomfort represent a promising research direction. Each of the seven discomfort factors might be used in such an interface. The Hassle factor could be implemented by giving users a task to search extra software or files. Alternatively, users could be asked to input some information such as the ID and password repeatedly. Further, the Waiting Time factor could be implemented so as to provide a user a block to complete an operation. Hayasaka et al. (2007) has conducted an experimental study on how a progress indicator could affect an operator's psychophysiological state. We could apply the results of his study to implement an interface that compels users to wait for a prolonged time by employing different methods to display a progress indicator. In addition, the Search Information factor could be implemented to prevent a user from acquiring content that $\mathrm{s} /$ he wants as easily as $\mathrm{s} /$ he expects. The Message factor could be implemented so as to provide a user with too many messages to confirm; alternatively, the messages could include nothing important. Further, the factor Unexpected Operation could be implemented so as to produce a sudden change on a user's display. With regard to the factors about "five senses" could be implemented so as to present users with sudden sounds or with text in hard-to-read combinations of the background and text colors.

It is possible to indicate multiple factors of discomfort together with one interface. We need to be mindful that if we cause too much discomfort to a user, the user will not use the system or services anymore. The needed amount of discomfort to work as an alarm to a user is an important topic of our future work. We need to design an interface with a control over how much discomfort can be caused.

Moreover, from the causal model that we examined, we need to take account of the fact that each discomfort factor affects the other discomfort factors; as a result, the feelings of discomfort may be amplified. We need some tuning mechanisms in the implementation of this model in the future. The implementation of such an interface and its evaluation to verify the factor structure is a future study, as is designing methods to quantitatively measure discomfort.

\section{Conclusion}

Our aim is to use an interface causing discomfort to alert the user about possible security threats. The seven factors of discomfort that were identified by carrying out exploratory factor analysis offered suggestions for the design and implementation of such an interface.

We intend to carry out an evaluation to verify the effects of the interface in a future study. It is possible to simultaneously indicate multiple factors of discomfort by using one interface. 
We need to be mindful of the fact that if we cause too much discomfort to a user, the user will not use the system or services anymore. The optimal amount of discomfort that would alert a user is an important topic that would be discussed in a future study. We need to design an interface that can control the amount of discomfort felt by a user. Moreover, in the causal model that we examined, we need to take account of the fact that each discomfort factor affects the other discomfort factors; as a result, the feelings of discomfort feelings may be amplified. Some tuning mechanisms need to be incorporated during the implementation of this model in future.

We are working on the development of the interface casing discomfort. We considered an access to a harmful link as an example; a different interface is necessary in other scenes. An interface causing discomfort is also useful to make users aware of careless operations such as sending an e-mail to another address by using an autocomplete function without paying attention.

\section{Acknowledgement}

Special thanks to Hitomi Oikawa graduated Graduate school of Software and Information Science, Iwate Prefectural University. Without her master's degree work this research was not possible.

\section{References}

Hikage, N., Murayama, Y. \& Hauser, C. (2007). Exploratory survey on an Evaluation Model for a Sense of Security, IFIP International Federation for Information Processing, Volume 232, New Approaches for Security, Privacy and Trust in Complex Environments, pp.121-132.

Murayama, Y., Hikage, N., Fujihara, Y. \& Hauser, C. (2007). The structure of the sense of security, Anshin, 2nd International Workshop on Critical Information Infrastructures Security, pp.85-96.

Xiao, S. \& Benbasat, I. (2004). Understanding Customer Trust in Agent-Mediated Electronic Commerce, Web-Mediated Electronic Commerce, and Traditional Commerce, Information Technology and Management, Vol. 5, No. 1-2, Kluwer Academic Publishers, pp.181-207.

McAllister, D.J. (1995). Affect- and cognition-based trust as foundations for interpersonal cooperation in organizations, Academy of Management Journal, Vol. 38, No.1, pp.2459.

Chopra, K. \& Wallace, W. A. (2003). Trust in Electronic Environments, Proceedings of the 36th Hawaii Interna-tional Conference on System Science (HICSS'03), p.331.1.

H.H Kuan. \& G.W. Bock (2005). The Collective Reality of Trust: An Investigation of Social Relations and Networks on Trust in Multi-Channel Retailers, Proceedings of the 13th European Conference on Information Systems (ECIS 2005), Available at: http:/ /is2.lse.ac.uk/asp/ aspecis/20050018.pdf (Last Access: 31 Mar 2009).

Luhmann, N. (2000). Familiarity, Confidence, Trust: Problems and Alternatives, in Gambetta, D. (ed.) Trust: Making and peaking Cooperative Relations, Department of Sociology, University of Oxford, pp.94-107.

Oikawa, H. (2008). A study of a causal structural model for a discomfort interface, master's thesis, Iwate Prefectural University. (in Japanese) 
Fujihara, Y., Oikawa, H. \& Murayama, Y. (2008). Towards an interface causing discomfort for security: A user survey on the factors of discomfort, Proceedings of 2nd IEEE International Conference on Secure System Integration and Reliability Improvement (SSIRI2008), pp.173-174.

Nielsen, J. (1993). Usability Engineering, Academic Press.

Norman, D.A. (1988). the Psychology of Everyday Things, Basic Books.

International Electrotechnical Commission (1996). Safety of household and similar electrical appliances - part 2: Particular requirements for microwave ovens (MOD IEC 60335-2-25).

Mackie, D. M. \& Worth, L. T. (1989). Processing deficits and the mediation of positive affect in persuasion, Journal of personality and social psychology, Vol.57 (1), pp.27-40.

Ishii, H. and Ullmer, B. (1997). Tangible Bits: Towards Seam-less Interfaces, between People, Bits and Atoms, Proceedings of the ACM Conference on Human Factors in Computing Systems (CHI 97), pp.234-241.

Sankarapandian, K., Little T. \& Edwards, W. K TALC: Using Desktop Graffiti to Fight Software Vulnerability, Proceedings of the ACM Conference on Human Factors in Computing Systems (CHI 2008), pp.1055-1064, 2008.

Egelman, S., Cranor, L. F. \& Hong, J. (2008). You've been warned: An empirical study of the effectiveness of web browser phishing warnings, Proceedings of the ACM Conference on Human Factors in Computing Systems (CHI 2008), pp. 1065-1074.

Wogalter, M. S. (2006). Communication-Human Information Processing (C-HIP) Model. In Handbook of Warnings, Wogalter, M. S. (Ed), Lawrence Erlbaum Associates, pp. 5161.

International Organization for Standardization (2002). Graphical symbols -Safety colors and safety signs- Part1: Design principles for safety signs in workplaces and public areas (ISO3864-1)

Ramsay. J. (1997). A factor analysis of user cognition and emotion, Proceedings of the ACM Conference on Human Factors in Computing Systems (CHI 97), pp.546-547.

Awad, N.F. \& Fitzgerald, K. (2005). The Deceptive Behaviors that Offend Us Most About Spyware, Communications of the ACM, Volume48, pp.55-60.

Takahashi, K., Nakatani, M. \& Nishida, S. (2002). Information Presentation from the standpoint of a sense of security, Proceeding of HIS 2002, pp.289-292. (in Japanese)

Tsuji, K., Okuda, T., Takahashi, K. \& Ito, T. (2005). Analyses of the discomforts aroused by stimulus sentences with reference to effects of modality and gender, The Japanese Journal of research on Emotions, Vol.3, pp.64-70. (in Japanese)

Hagiwara, H. (2006). Sensory Aversion Degrees for Adolescents, Bulletin of Junior College of Shukutoku, Vol.45, pp.89-113. (in Japanese)

Harman, H. H. (1976). Modern factor analysis, 3rd edition. Chicago, IL: University of Chicago Press.

Yamazaki, M. \& Kikkawa, T. (2006). The Structure of Anxiety Associated with Avian Influenza and Pandemic Influenza, the 47th annual conference of the Japanese Society of Social Psychology, pp.676-677. (in Japanese)

Bollen, K. A., \& Long, J. S. (1993). Testing Structural Equation Models. Newbury Park, CA: SAGE Publications.

Kline, R. B. (2005). Principles \& Practice of Structural Equation Modeling. New York, NY: The Guilford Press. 
Hayasaka, Y., T. Kimura, Segawa, N., Miyazaki, M., Yamazaki, K. \& Murayama, Y. (2007). A Study on Effects of Waiting Period in Software Operation on the Operator's Psychophysiological State. Transactions on Electronics, Information and Systems of the Institute of Electrical Engineers of Japan, Vol.127, No.10, pp.1770-1779. (in Japanese) 


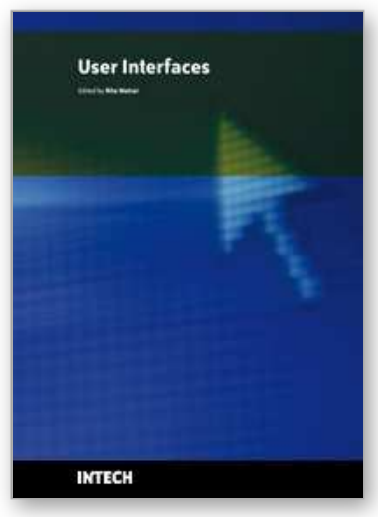

\author{
User Interfaces \\ Edited by Rita Matrai
}

ISBN 978-953-307-084-1

Hard cover, 270 pages

Publisher InTech

Published online 01, May, 2010

Published in print edition May, 2010

Designing user interfaces nowadays is indispensably important. A well-designed user interface promotes users to complete their everyday tasks in a great extent, particularly users with special needs. Numerous guidelines have already been developed for designing user interfaces but because of the technical development, new challenges appear continuously, various ways of information seeking, publication and transmit evolve. Computers and mobile devices have roles in all walks of life such as in a simple search of the web, or using professional applications or in distance communication between hearing impaired people. It is important that users can apply the interface easily and the technical parts do not distract their attention from their work. Proper design of user interface can prevent users from several inconveniences, for which this book is a great help.

\title{
How to reference
}

In order to correctly reference this scholarly work, feel free to copy and paste the following:

Yasuhiro Fujihara and Yuko Murayama (2010). A User Survey on the Interface Causing Discomfort for Warning, User Interfaces, Rita Matrai (Ed.), ISBN: 978-953-307-084-1, InTech, Available from: http://www.intechopen.com/books/user-interfaces/a-user-survey-on-the-interface-causing-discomfort-forwarning

\section{INTECH}

open science | open minds

\author{
InTech Europe \\ University Campus STeP Ri \\ Slavka Krautzeka 83/A \\ 51000 Rijeka, Croatia \\ Phone: +385 (51) 770447 \\ Fax: +385 (51) 686166 \\ www.intechopen.com
}

\author{
InTech China \\ Unit 405, Office Block, Hotel Equatorial Shanghai \\ No.65, Yan An Road (West), Shanghai, 200040, China \\ 中国上海市延安西路65号上海国际贵都大饭店办公楼 405 单元 \\ Phone: +86-21-62489820 \\ Fax: +86-21-62489821
}


(C) 2010 The Author(s). Licensee IntechOpen. This chapter is distributed under the terms of the Creative Commons Attribution-NonCommercialShareAlike-3.0 License, which permits use, distribution and reproduction for non-commercial purposes, provided the original is properly cited and derivative works building on this content are distributed under the same license. 